\title{
WEED TRAINING MANUAL
}
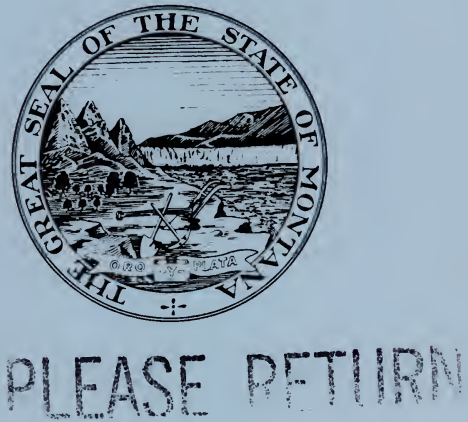

MONTANA DEPARTMENT OF AGRICULTURE ENVIRONMENTAL MANAGEMENT DIVISION HELENA, MONTANA 59620-0205 JANUARY, 1986 
14y 291908

AUG 101988

$\therefore$ *

JUL 2 \& 81993

FEB 222002 
This manual was prepared as a study guide for all commercial applicators engaged in weed control work and herbicide application as well as for all weed district personnel. It includes information on chemical control of weeds, alternate control methods, environmental factors influencing herbicide action, toxicity of herbicides and environmental hazards associated with herbicide use. The manual can be used as a study guide for agricultural plant pest and regulatory weed tests. It can also be used as a general reference on weed control, regulations governing weed control and Montana noxious weeds.

To simplify information, trade named products and equipment have been mentioned. No endorsement is intended, nor is criticism implied of similar products or equipment which are not mentioned.

We wish to acknowledge the help of the personnel of the Enivronmental Management Division, Montana Department of Agriculture, in preparing this manual.

For a copy of any pertinent weed laws or any additional information, please contact:

Montana Department of Agriculture Environmental Management Division Agriculture/Livestock Building Capitol Station

Helena, Montana 59601 (406) 444-2944 
.

0

0 
TABLE OF CONTENTS

Page

PREFACE

CHAPTER I. INTRODUCTION TO WEEDS. . . . . . . . . . . . . . 1

A. Sources of Infestation. . . . . . . . . . . . . 2

ChAPTER II. ClASSIFICATION OF WEEDS. . . . . . . . . . . . 4

A. Habitat . . . . . . . . . . . . . . 4

B. Life Cycle.................. . . 4

C. Plant Structure . . . . . . . . . . . . 6

CHAPTER III. METHODS OF CONTROLLING WEEDS . . . . . . . . . 7

A. Prevention. . . . . . . . . . . . . . 7

B. Cultural and Mechanical Control . . . . . . . . 7

C. Biological control. . . . . . . . . . . . 8

D. Chemical Control. . . . . . . . . . . . . 10

E. Weed Control versus Weed Management . . . . . . . 11

CHAPTER IV. CHEMICAL WEED CONTROL. . . . . . . . . . . . 12

A. Selective Herbicides. . . . . . . . . . . . 12

B. Non-Selective Herbicides. . . . . . . . . . . 13

C. Basics of Herbicide Selectivity . . . . . . . . .14

D. Herbicide Formulations. . . . . . . . . . . .17

E. Spray Additives . . . . . . . . . . . . . 18

F. Mixtures of Herbicides with other Pesticides

or Fertilizers. . . . . . . . . . . . . . 19

G. Herbicide Application . . . . . . . . . . . 21

CHAPTER V. CHEMICALS USED AS CROP AIDS. . . . . . . . . 22

A. Defoliants and Desiccants . . . . . . . . . . . 22

B. Plant Growth Regulators . . . . . . . . . . . . 22

CHAPTER VI. ENVIRONMENTAL FACTORS INFLUENCING

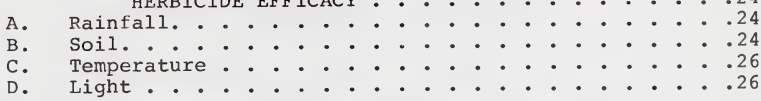

CHAPTER VII. WEEDS AND HERBICIDES IN THE ENVIRONMENT. • • . . 27

A. Drift and Volatility of Herbicides. . . . . . . . 27

B. Protection of Non-Target Plants . . . . . . . . . 28

CHAPTER VIII. TOXICITY OF HERBICIDES . . . . . . . . . . . . . 30

A. Toxicity Classification . . . . . . . . . . . 30

B. $\mathrm{LD}_{50}$ Values . . . . . . . . . . . . . . . . 31

CHAPTER IX. PERENNIAL WEEDS IN MONTANA . . . . . . . . . . 33

A. Borage Famil. . . . . . . . . . . . . . . 34

B. Sunflower Family. . . . . . . . . . . . . . 35

C. Morningglory Family . . . . . . . . . . . . . . . . . . . 44

D. Mustard Family. . . . . . . . . . . . . . . . . . . . . . 
TABLE OF CONTENTS

Page

E. Spurge Family . . . . . . . . . . . . . . 47

F. St Johnswort Family . . . . . . . . . 4 . . 4 48

G. Watermilfoil Family . . . . . . . . . . . . . 49

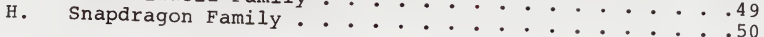

APPENDIX A. CLASSIFICATION OF HERBICIDES BY CHEMICAL

FAMILIES AND MODE OF ACTION. . . . . . . . . 51

APPENDIX B. SELECTED BIBLIOGRAPHY. . . . . . . . . . . . . . . . . 44 
CHAPTER I

\section{INTRODUCTION TO WEEDS}

Most of the plants that we commonly consider weeds have existed in the world for many years but were not economically important until man started growing plants for food. Weeds are objectionable because they have the ability to compete with plants grown for food, animal feed and fiber.

A weed can be defined in many ways: 1) a plant growing where it is not wanted; 2) a plant out of place; or 3) a plant that is more harmful than beneficial. Any plant can be a weed in a given circumstance. Kentucky bluegrass that spreads into a flower bed is a weed; volunteer wheat in a sugar beet field is a weed. A plant is a weed only in terms of individual definition.

The plants that are commonly referred to as weeds have characteristics that give them the ability to spread and compete well with most cultivated plants. Most major weeds have at least several of the following characteristics:

1. Continuous seed production for as long as growing conditions permit;

2. Unique ways of dispersing and spreading, including vegetative propagation and seed production;

3. Ability of seeds to remain dormant in soil for long periods of time;

4. Ability to grow under adverse conditions;

5. Adaptation to a wide variety of soil and climatic conditions;

6. Compete well for soil moisture, nutrients and sunlight;

7. Genetic adaptability, a wide gene base for competition with crop plants.

Economic losses caused by weeds occur every year in Montana. Weeds cause losses to agricultural production by:

1. Decreasing crop yields by removal of water and nutrients from the soil. Many weeds need more water to produce one pound of dry matter than do most of the cereal grains.

2. Weed seeds in grain reduce the value of these products. 
3. with an odor or off-flavor. preparing soil for planting. water flow and added weed control costs.

6. Weed infestations may serve as a source of plant diseases and insect pests. Weeds may also act as alternate

7. Some weeds are poisonous to humans and livestock if

To pl sduce crops efficiently, it is necessary to reduce the effect of competition by weeds. Although weeds cannot be entirely eliminated, they can be reduced to manageable levels.

\section{A. SOURCES OF WEED INFESTATION}

Man is probably the most active agent in the dissemination of to the movemexotic weeds found in the United States are here due man in many ways or man areds. Weed seeds are moved by by machinery and vehicles. in hay and seed products as well as hauling cargoes of grain. Common carriers, railroads and trucks commodities scatter may, livestock, and other farm which in turn becomes Wind spreads seeds over great distances. Many weed seeds have structural features which aid their distribution by wind. Some long, silky hairs or parase of maple trees, or they may have are especially adapted for them. Tumbleweeds wind. Russian thistle, for seed dispersal along the ground by when mature and rolls, for example, breaks off at the soil line it goes.

Water is another method of seed dispersal. Most weed seeds will canals. Flood waters, the surface of streams, lakes or irrigation all important in spreading weed seeds, and irrigation water are first filled, often carry heavy loads. Irrigation canals, when where they may be washed ashore loads of weed seeds downstream way.

Wild and domestic animals also aid in the dispersal of seed. The digestive tracts of animals. sandbur, and beggar-ticks have Many weeds, such as cocklebur, attach to the hair of animals. 
Planting impure small grain, legumex or grass seed is another way to spread weed seeds. Farmers actually drill seeds into the soil when planting their crops. The planting of certified seed can prevent the spread of weeds. Also, mechanical seed cleaning can remove weed seeds from grain prior to planting.

Farm machinery can also spread weed seeds, especially in wet weather when seeds stick to muddy implements and vehicles. Plows and cultivators drag roots, rhizomes, tubers or seeds to other areas. Combines and hay balers spread weed seeds from field to field. All farm machinery should be cleaned before moving it from one area to another. 
0

.

○ 


\section{CHAPTER II}

\section{CLASSIFICATION OF WEEDS}

Weeds can be classified in several different ways: by plant habilat, life cycle, or plant structure. A discussion of each classification is important because identification and control practices are influenced by these classifications.

\section{A. HABITAT}

Plant habitat refers to where the plant grows. Terrestrial plants live on land while aquatic plants are structurally modified to live in and around water. For a more complete discussion of aquatic vegetation refer to the Montana Department of Agriculture's "Aquatic Weed Training Manual."

\section{B. LIFE CYCLE}

The life cycle (or growth habit) of each weed species describes how long each plant lives and timing of vegetative development.

Annuals complete their life cycle from seed to mature plant in less than one year. Summer annual seeds germinate in the spring, flower and produce seed in mid-to late-summer, and die in the fall. Winter annual seeds germinate from late summer to early spring, flower and produce seed in mid-to late-spring and die in the summer. Classification of winter or summer annuals often depends on geography and climate.

Kochia, lambsquarters, redroot and prostrate pigweed, Russian thistle, green and yellow foxtail, and crabgrass are all examples of summer annuals. Winter annuals include common chickweed, downy brome, and many of the mustards.

Control of annual weeds must be accomplished before the plant produces seed. This is most effective when the plant is in the seedling stage. Weeds are small and succulent and less energy is required for control at this stage. Control. during the vegetative stage is possible but more difficult since the plant is putting energy into the production of stems, leaves and roots. Chemical control of annuals during the flowering stage is not feasible because most of the plant's energy is going into seed production. Maturity and seed set completes the annual plant ife cycle. Control is not effective at this stage. 


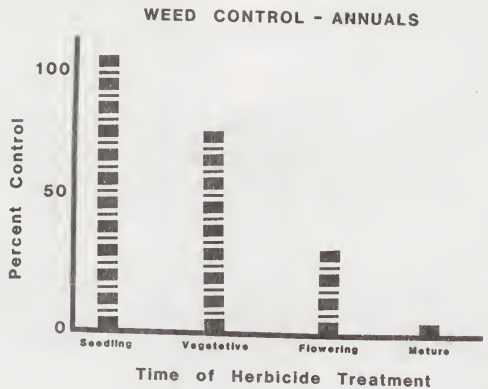

Biennials live for two growing seasons. Seeds germinate in the spring, summer, or fall of the first year and plants overwinter as a basal rosette of leaves with a thick storage root. The plants flower and produce seed the summer of the second year and die in the fall. Common biennials include mullein, burdock, wild carrot, bull thistle and musk thistle.

Effective control of biennial plants is very similar to control for annuals. Early spring or fall spraying of the rosette is an effective time for control.

Perennials produce vegetative structures, allowing them to live for more than two years. They reproduce by seed in addition to spreading vegetatively. Simple perennials overwinter by means of a vegetative structure, such as a perennial root with a "crown," but they reproduce almost entirely by seed. Creeping perennials both overwinter and produce new, independent plants from vegetative reproductive structures. These structures include rhizomes, tubers, bulbs, stolons and creeping roots. Most creeping perennials can also reproduce from seeds.

Dandelion and curly dock are common examples of simple perennials. Quackgrass, Canada thistle, leafy spurge and field bindweed are creeping perennials.

Perennial weed control must be aimed at either the seedling or the regrowth stages of development. Chemical control during the vegetative growth stage is mediocre. Control during flowering is ineffective but is effective just prior to flowering (bud stage). Control at maturity is not feasible since the above ground portions of the plant die back at this time. Fall treatment of regrowth is most effective because the plant is translocating nutrients to the root system and will also translocate herbicide to kill the roots. To achieve effective control of perennials, 
WEED CONTROL - PERENNIALS

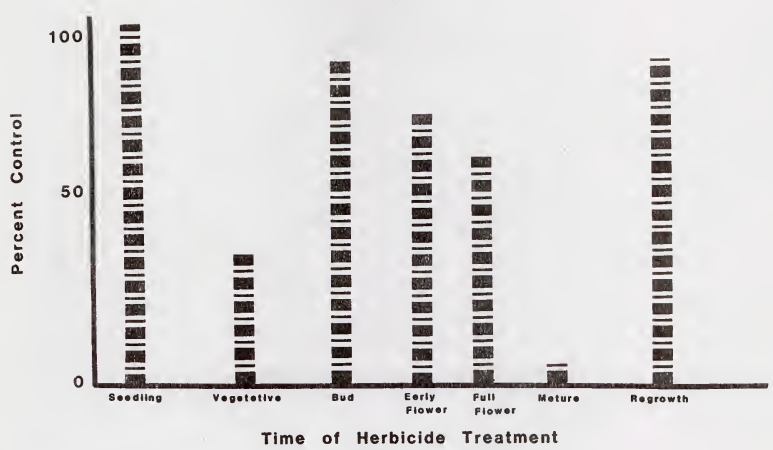

C. PLANT STRUCTURE

Differences in plant structure or morphology are important to recognize. For weed control purposes plants are divided into three main categories - grass, broadleaf and woody.

Grass plants have one seed leaf (monocot). They typically have parallel. leaf venation, narrow, upright leaves and flower parts in threes or multiples of threes. Examples include quackgrass, green foxtail and downy brome.

Broadleaf plants have two seed leaves (dicots). They generally have broad, net-veined leaves and flower parts in four, five or multiples thereof. Examples include kochia, sunflower, and Canada thistle.

Woody plants persist from year to year with woody aerial stems and include brush, shrubs, and trees. Brush and shrubs have several stems and are generally less than ten feet tall. Trees have a single stem and are over ten feet tall. Multiflora rose, sage brush and buckbrush are examples of woody weed plants. 
0 
METHODS OF CONTROLLING WEEDS

For a weed control program to be successful, weeds or undesirable plants must be destroyed without damaging crops or desirable plants. The most effective or ecoromical method or combination of methods for weed control depends upon the situation. Herbicides are a supplement to good cultural and management practices and are not a replacement for them.

Good farming and land management practices should be first in any weed control program. Causes of weed problems should be identified and corrected by implementation of an integrated management program, including all effective control methods.

Methods that can be used for weed control include: 1) prevention, 2) cultural and mechanical control, 3) biological control, and 4) chemical control.

\section{A. PREVENTION}

Prevention is the most practical method of controlling weeds. If weeds are not allowed to infest an area and produce seed they will not establish. Once weeds are established they are difficult and costly to control and may persist for many years as dormant seeds in the soil.

Preventative control measures should be adapted where practical and include: a) the use of clean seed; b) clean all implements, vehicles, and harvesting equipment before moving it from infested areas; c) keep irrigation ditches, fence rows, roadsides and other non-crop areas free from weeds; d) do not bring infested soil, hay, straw, or manure into clean areas; 3) spot treat small infestations or isolated individual plants; and f) do not allow new plants to set seed.

\section{B. CULTURAL AND MECHANICAL CONTROL}

Cultural and mechanical control includes tillage, hoeing, mowing, mulching, crop competition, and crop rotation.

Cultivation stimulates the germination of weed seeds by bringing them to the soil surface. These weed seedlings are then easily controlled with a second tillage operation. Tillage is effective on annual weeds; however, repeated tillage operations (every two to three weeks throughout a season) may be needed to control perennial weeds.

Mowing can be an effective weed control practice under certain conditions. It should be part of an overall crop management program. Mowing controls weeds by preventing seed production, depleting underground food reserves, and by favoring growth of more competitive plants. Plants must have a relatively tall 
growth habit to prevent seed production. Mowing must be done prior to pollination and fertilization. Since most plants regenerate, repeated mowing is required for adequate weed control. It is important to remember that repeated mowing may change upright, single stemmed plants into prostrate, several stemmed plarits that can still set seed.

Mulches control weeds by excluding light. They are most effective on small areas with high value crops that are already established, such as tomato transplants or flower plantings. Mulching material should be thick enough to exclude light, relatively cheap, and easy to work with. Straw, sawdust, wood chips, bark chips, grass, heavy plastic and paper clippings are all good mulches. Perennials are difficult to control with mulches due to the persistent nature of their vegetative growth.

Crop ccmpetition is probubly the cheapest and easiest method of control_ing weeds. A crop will flourish if it can compete more efficiently than weeds for sunlight, water, nutrients, and space. Early spring seeding can allow cereal grains to germinate earlier than weeds. If the crop is established before the weeds germinate, it will often crowd out the weeds. Early weed competition often takes needed nutrients and water from a crop.

"Smother" crops may be valuable in a weed control program. They compete with weeds for water, light, and nutrients. The main competitive crops valued in weed control are crested wheatgrass, sweet clover, sunflower, rape, barley, rye, soybeans, alfalfa, and silage corn. These crops grow quickly, produce an abundance of shade, and can be harvested early enough to permit fall cultivation. It has been shown in Saskatchewan that four seasons of crested wheatgrass have completely smothered a solid stand of Canada thistle, quackgrass, and other perennial weeds.

Crop rotation is another good method for weed control. Certain crops have their own characteristic weeds, and these weeds tend to accumulate when the same crop is repeated year after year. These repeated plantings favor disease and insect problems resulting in weak, patchy stands which are easily invaded by weeds.

Using several cultural and mechanical controls, such as tillage and competitive crops, can give encouraging results in the control of all classes of weeds, including deep-rooted perennials.

\section{BIOLOGICAL CONTROL}

Biological weed control is the use of a living organism to control weeds. Insects are the most commonly used agent but fish, nematodes, snails, fungi, and bacteria offer additional means of controlling plants. 
Biological controls can be useful for suppression of unwanted plants, generally in a non-crop situation. Development of a biocontrol agent is time-consuming and expensive. Research is needed to find host specific agents and usually several different agents are needed to give economic control of a single weed species. Biological control is not recommended in cropland situations due to a lack of adequate economic threshold data for weeds. In a field situation, there are usually several other weed species that will fill in a void left by one plant taken out by a biological control agent.

There are several excellent examples of weed control by insects. The most outstanding is cactus control in Australia. Over 60 million acres of infested land were reclaimed using a moth assisted by a scale insect. Another example is found in California and the Pacific Northwest where goatweed has been reduced on millions of acres to about 18 of its former range.

Some results in Montana using biocontrol agents include:

1. The goatweed beetle Chrysolina hyperici, was first introduced to Montana in 1948. Many additional colonies have been released, the latest in 1971. The beetle has only survived in a few locations. In spite of the slow response, researchers are optimistic about future success with this insect. Periodic collecting of beetles from areas of good establishment and their release in areas of low beetle populations may provide for better control. Other insects are being investigated for goatweed control.

2. While a flea beetle has not been successful in establishing itself on Canada thistle, another insect, Ceutorhynchus litura, has overwintered and is slowly spreading.

3. A weevil, Rhynocyllus conicus, has proven itself well adapted by increasing in large numbers on musk thistle in the Gallatin Valley and other areas of Montana.

4. A gallfly, Urophora affinis, has been released in Western Montana for spotted knapweed control. It has overwintered, increased in numbers, and is slowly dispersing from the release site. Work continues on cther agents to attack spotted and diffuse knapweed.

5. Dalmation toadflax control by a foliage eating moth, Calophasia lunula, is being investigated. Evidence of overwintering has not been found in Montana.

6. Spread of common toadflax has been reduced by a seed weevil, Gymnaetron antirrhini. A survey to determine spread of this insect and areas of release is needed. 
7. Leafy spurge control has been attempted with a hawkmoth (Hyles euphorbiae) that has been released in several locations in the state. This insect defoliates the plant and could be effective in conjunction with other stress on leafy spurge.

8. Work is being done on development of a fungus, Sclerotinia sclerotiorium, that attacks Canada thistle, spotted knapweed and yellow starthistle.

9. Sheep and goats can be used to suppress growth and prevent seed production of leafy spurge in environmentally sensitive areas.

\section{CHEMICAL CONTROL}

Use of herbicides for weed control is common in Montana. Researcl. over the past few decades has produced increased knowledge and many new chemicals for use in weed control. Chemicals are now widely used and will continue to play an important role in agriculture.

A fairly recent technique for weed control is the increased use of chemicals in a fallow operation to reduce tillage. This method is referred to as no-till, ecofallow, chemical fallow, and reduced or minimum tillage.

Some possible advantages of a minimum tillage system include:

1. Use of hilly, rocky, or rough land where tractor

tillage is difficult,

2. Reduction of field and human energy requirements,

3. Reduction of water and wind erosion of soil,

4. Improvement of soil structure,

5. Conservation of soil moisture and organic matter, and

6. Saves time.

Disadvantages to this system include:

1. Possible increase of insect, disease, and vertebrate

2. Perennial weeds must be controlled under an herbicide program or they will increase,

3. Soil temperatures in the spring are lower under a mulch and germination of warm season crops, such as corn, can be 
4. Soil must be loosened for planting of certain root and tuber crops.

With increased fuel costs and fuel shortages, reduced tillage will probably gain in popularity. As long as its limitations are understood, it can be an effective tool in the fight against weeds.

\section{E. WEED CONTROL VERSUS WEED MANAGEMENT}

Specific weed control methods have been outlined in this chapter. All of these tools must be used to effectively manage weed infestations. Annual, biennial, and perennial weeds have certain growth habits that influence the type of control methods or methods implemented. Soil type, weather conditions, recreational activity, wildlife or domestic grazing and future use of the land will also influence your choice of weed control tools. Consider all information known about the weed and the site as you develop a long term management plan for control of a weed infestation. 
0 
Herbicides are effective tools when used properly. Since the early $1950^{\prime} \mathrm{s}$, thousands of chemicals have been evaluated for effectiveness as weed killers. Safe and effective herbicides are available for controlling many weeds growing in various environments including cropland, rangeland, gardens, lawns, ditchbanks, non-crop areas, and in irrigation, drainage, navigable, and potable waters. Because of the many factors and principles involved in research on herbicides, information about chemical weed control is rapidly increasing. New recommendations are continually replacing old ones. Be sure to read and follow all label directions from a current product label.

\section{A. SELECTIVE HERBICIDES}

Chemicals which can be used to remove certain plant species with little or no effect on other species are referred to as selective herbicides. Selectivity depends on the amount of chemical used, the application method, the degree of foliage wetting, soil moisture and texture, temperature, and humidity. Since selectivity can be influenced by all of these factors, the same chemical may be either selective or non-selective, depending on the amount used. For example, atrazine used at a high rate is an effective soil sterilant (non-selective) and used at a lower rate is a selective herbicide for weed control in corn.

1. Foliage applications are treatments made to the leaves of growing plants, usually as a spray or mist.

a. Translocated herbicides move within the plant after the material is absorbed into the tissue. The greatest amount of transport is through the vascular system of the plant (phloem and xylem). Translocated herbicides may be effective in destroying roots as well as top growth of plants. Selectivity depends on physiological differences of plants. 2,4-D is a commonly used selective, translocated herbicide used in Montana.

b. Contact herbicides do not translocate or move in the plant. This group of herbicides kills only the plants or portion of the plant actually contacted by the chemical. In order to obtain effective control, adequate coverage of the foliage is essential. This may be accomplished by using a high volume of carrier or diluent to apply the herbicide. Dinitrophenols and certain petroleum oils are used as selective, contact herbicides. 
2. Soil applications are herbicide treatments applied to the soil. To be effective, the chemical must be carried into the soil by moisture or mechanical incorporation. Selectivity depends on the plant tolerance, soil texture, location of the herbicide in the soil, and difference in growth habit of the crop and the weed. These herbicides are generally translocated.

3. Selectivity can also be determined by timing of applications:

a. Preplant treatments are made to the soil before the crop is planted. Typical preplant treatments are applied after seed bed preparation but directly before planting the crop. This type of treatment is considered pre-emergence with respect to weeds if applied prior to weed germination.

b. Pre-emergence treatments are made to the soil after the crop is planted but before emergence of the crop or the weeds.

c. Post-emergence herbicides are applied to the soil after the crop or weeds have germinated and started to grow. Other post-emergence treatments may include:

1) Pre-harvest herbicide treatment applied before crop harvest to remove weed growth that could interfere with the harvesting operation.

2) Post-harvest herbicides applied to kill weeds present after harvest as part of the weed control program for the next season.

\section{B. NON-SELECTIVE HERBICIDES}

Herbicides which are toxic to all plants may be used to control a wide variety of vegetation in an area. When no selectivity is intended, these chemicals can be used to control vegetation in non-cropped areas such as along fence rows, around electrical power lines and substations, right-of-ways, and storage areas.

1. Foliage applications are applied to the leaves of growing plants as sprays or mists.

a. Translocated herbicides move from the foliage to the roots, resulting in control of a wide variety of plant species. There are few herbicides that can be classified as translocated, non-selective. Glyphosate is one good example.

b. Contact sprays kill vegetation at the point of contact. One treatment is usually sufficient to 
control annual weeds. Perennial plants may require more than one treatment for adequate control. Acrolein and paraquat are examples of non-selective contact herbicides.

2. Soil applications include a wide variety of soil fumigants and soil sterilants that are applied directly to the soil. These are used where it is necessary to remove all plant growth.

a. Soil fumigants are non-selective chemicals that are most often used to kill all plant growth as well as other soil organisms before planting a desirable species. They function as a vapor or gas which diffuses through the soil and has a short life in the soil. The treated area may be replanted, usually within a month or less. Methyl bromide is a commonly used soil fumigant.

b. Soil sterilants are chemicals that kill all green plants for a period of up to two or more years. They are classified as:

1) Temporary sterilants which kill plant life for four months or less.

2) Semi-permanent sterilants which kill all plant life for four months to two years.

3) Permanent sterilants which persist in the soil for longer than two years.

The length of time the herbicide residue remains depends on the herbicide used, the rate of application, and the soil moisture and texture.

\section{BASICS OF HERBICIDE SELECTIVITY}

It is important to understand how herbicides kill plants, why a herbicide is phytotoxic to one species and not another, and how herbicides can be used to best accomplish the results desired. selectivity is relative. We want to obtain the maximum difference in resistance between the crop and the weed.

The most important factors that affect herbicide selectivity are: 1) structural differences in plants, 2) differences in absorption, 3) differences in translocation, 4) physiological differences, and 5) herbicide concentration. Combinations of these factors can be used to improve herbicide selectivity.

1. Structural differences among plants permit selective applications. The narrow, upright leaves of a cereal plant lack the exposed leaf surfaces of a broadleaf plant. Water droplets can stick only to a small portion of an upright 
leaf surface. On the other hand, a broadleaf plant has a wide leaf surface which extends parallel to the ground and will hold more spray and therefore be affected more by the herbicide. Another important structural difference is the location of the growing point of the plant. The growing point of many grasses is protected because it is located at the base of the plant. Contact sprays may injure the leaves of the grass plant but not contact the growing point. Broadleaf plants have exposed growing points at the tips of the shoots and in the leaf axils. The growing point is therefore more accessible to the herbicide.

Waxiness, hairiness, or pubescence of a plant may prevent spray droplets from adhering to the leaf. If the chemical droplet adheres to the leaf hairs without contacting the leaf surface, it will not be absorbed. On the other hand, h، irs may collect and hold greater amounts of droplets, prcventing the spray from running off the leaf surface. Waxy leaves may require use of an additive with the herbicide to dissolve the waxy layer and allow contact with the leaf surface.

2. Absorption is the movement of a material into the plant from an external source. Some plant surfaces absorb herbicides quickly; other surfaces may absorb the chemical slowly, if at all. Parts of the plant leaf surface, the cuticle and the stomate, account for differences in absorption.

a. The cuticle is a waxy layer or thin film on the leaf surface which retards the movement of water and gases (oxygen and carbon dioxide) into and out of the leaf. The cuticle varies in thickness in different plants and can vary within the same plant exposed to different environmental conditions. Shaded plants often have thinner cuticles than plants grown in the sun, and young leaves usually have thinner cuticles than older leaves. An herbicide must penetrate the cuticle layer and cell wall. High temperature and low humidity usually result in poor cuticle penetration.

b. A plant leaf is perforated by small openings or pores called stomates; these open into the intercellular spaces within the leaf. The number and distribution of the stomates varies from plant to plant. The stomatal opening can be an effective port of entry of the herbicide if they are open at the time of application. This is why some foliar applied sprays are more effective when applied in the early morning or late evening when there is less sunlight and the stomates are more likely to be open. Stomatal penetration cannot occur unless the surface tension of the spray solution is significantly reduced by the use of wetting agents. 
3. After the herbicide is absorbed, it must be translocated within the plant to the site of action. There are two tissue systems in which an herbicide may move in the plant: the phloem, which conducts food from the plant leaf to the stem and roots; and the xylem, which conducts water and nutrients from the roots to the stem and leaves. Herbicides move through these conducting tissues to other parts of the plant.

a. Phloem tissues are composed of living cells. It is important, therefore, not to kill the stem and leaf tissues too quickly. Rapid foliage kill will result in poor transport and poor root kill. Movement in phloem will be toward the roots during maturation of the plant and near budding. This indicates the importance of proper timing of an herbicide application, especially for the control of perennial weeds. It is necessary to apply a translocated herbicide when a perennial is storing up root reserves. Most growth regulators, including 2,4-D, as well as amitrole, dalapon, and glyphosate, move readily in phloem tissue.

b. Xylem tissue of a plant is made up of non-living cells. It is the water conducting, transpiration system in the plant and movement is only from the roots upward to leaf and shoot tips. Any chemicals applied either to the roots or foliage will only be translocated toward the leaf tip. Atrazine, metribuzin, and diuron are examples of xylem conducted herbicides.

4. The physiological differences between plants affect herbicidal toxicity. Differences in enzyme systems, responses to $\mathrm{pH}$ changes, cell metabolism, cell permeability, variations in chemical constituents and polarities may all influence the selectivity of an herbicide to plants. Any herbicide that stimulates or blocks certain biochemical processes in a plant can affect the plant's growth and cause herbicidal action. Enzyme reactions may be blocked in one plant species, but not in another, by the same chemical. Activation of chemical into an active compound, such as $2,4-\mathrm{DB}$ converted to $2,4-\mathrm{D}$ by certain plants, is an example. Decomposition of an herbicide to a harmless compound is another example; corn has enzymes that can decompose triazine herbicides into harmless compounds.

5. The rate of application or concentration may determine whether an herbicide inhibits or stimulates plant growth. Under low concentrations 2,4-D can act as a growth hormone and increase the rate of respiration and cell division, resulting in stimulated plant growth. At higher rates, growth is excessive and results in death of the plant. The concentration of an herbicide at certain sites in the plant may determine the herbicide effectiveness. 
Almost all herbicides must be combined with a liquid or solid carrier to uniformly distribute them during application. The formulation of a chemical is the manner in which the active ingredient and the carrier are mixed. Proper formulation of agricultural chemicals increases their effectiveness. Inert ingredients make the herbicide easier to handle, less likely to settle out or decompose during storage, and may minimize the hazard of handling the chemical. The way the herbicide is formulated may change its chemical characteristics, including solubility, volatility, and toxicity to plants.

Common types of formulations are classified as follows:

1. Liquid Formulations

a. Emulsifiable concentrates (EC) are nonpolar (oily) liquids containing emulisifiers, a substance promoting the suspension of one liquid in another. The active ingredient is not soluble in water, but is dispersed in water to form emulsions (droplets of oil surrounded by water). Agitation is usually required to prevent separation.

b. Solution(s) are herbicides (liquid or powder) that are directly and rapidly soluble in the carrier liquid. These require no agitation once dissolved in solution. often they need a surfactant for maximum activity.

c. A suspension consists of a finely ground wettable powder (WP) dispersed in a liquid. Wettable powders are used if a solid concentrate is preferable to a liquid or if the solubility of a herbicide is so limited that it is impossible to formulate an economical solution or emulsifiable concentrate. These herbicides are nearly insoluble in water or oil but may be dispersed in them by forming a slurry, adding it to the carrier and using constant agitation.

d. Water dispersible liquids and granules are often referred to as flowables (F) or dry flowables (DF). These formulations readily disperse in the herbicide carrier. They require a moderate amount of agitation. Both liquids and granules can be added to water without first making a slurry. Water dispersible granules pour cleanly from the container, giving them handling advantages over dispersible liquids and wettable powders.

2. Dry Formulations

a. Granule formulations have been impregnated into coarsely ground carriers such as clay or vermiculite 
and formed into small pellets, generally less than 10 $\mathrm{mm}$ in size. These chemicals are used directly from the bag but require special application equipment, and usually require soil incorporation to be effective.

b. Pellets are discrete particles usually larger than $10 \mathrm{~mm}$. They are frequently used for spot treatments.

c. Dusts are finely ground chemicals that may or may not be mixed with diluents. Their use is limited because of the hazard of drift and the high cost of the herbicide.

\section{E. SPRAY ADDITIVES}

Adjuvants or spray additives are often used to enhance herbicidal performance or handling. They include surfactants, anti-foaming agents, compatibility agents, crop oils, crop oil concentrates, and drift control agents.

1. Surfactants (surface-active agents) bind two or more incompatible phases, such as water and oil, in more intimate contact by modifying forces between them. A surfactant is any material that affects the surface properties of spray solutions and includes wetting agents, emulsifiers, dispersing agents, detergents, and stickers.

a. Wetting agents are materials used to increase a liquid's ability to moisten a solid. They lower the surface tension, bringing the liquid into closer contact with the solid. Wetting agents increase or decrease the effectiveness of herbicide sprays; they may also reduce selectivity, especially if selectivity depends on selective wetting or selective absorption.

b. An emulsifier is a material used to disperse one liquid in another. An emulsion is one liquid dispersed in another, each maintaining its original identity.

c. Dispersing agents reduce cohesion between particles. They are materials used to disperse the particles of a solid in a liquid. Some dispersing agents also act as wetting agents, but others have little or no effect on surface tension. Some wetting agents and dispersing agents are not compatible and interfere with each other if used together.

d. Detergents are used to remove dirt or grime. They are usually wetting agents and surface active. Many common detergents have been used with herbicides as wetting agents and emulsifiers. Antifoaming agents can be used to reduce foaming in a sprayer system so pumps and nozzles can operate properly. 
e. A sticker is designed to hold the active ingredient on the sprayed surface.

f. A penetration agent is any substance that assists plant absorption of an herbicide. Such substances may dissolve the waxy cuticle or fatty portion of the cell wall or membrane of the plant to allow more rapid penetration.

g. Anticaking agents are used to prevent solid herbicide formulations from forming aggregates.

Surfactants are classified as ionic and nonionic, depending on their disassociation in water. Nonionic agents have no particle charge, while ionic agents have either a positive or negative charge.

Nonionic surfactants are classed as nonelectrolytes and are usually chemically inactive in the presence of usual salts. They can be mixed with most herbicides and still remain chemically inactive. Ionic surfactants ionize in an aqueous medium. These agents can be used to unite oil or water soluble properties of a molecule and allow alignment in water to reduce water surface tension.

2. Compatibility agents aid suspension of herbicides when they are combined in tank mixes with other pesticides, herbicides or fertilizers. They are used frequently when a liquid fertilizer is the carrier solution.

3. Crop oil and crop oil concentrates are non-phytotoxic light oils that also contain surfactants to allow mixing with water. They are added to water solutions to enhance herbicide foliar activity.

4. Drift control agents reduce the fine particles in a spray pattern that are primarily responsible for herbicide drift and nontarget injury.

All adjuvants should be used in accordance with label directions and chosen only from those proven effective for herbicide applications. Refer to the manufacturer's recommendations and herbicide label recommendations.

F. MIXTURES OF HERBICIDES WITH OTHER PESTICIDES OR FERTIIIZERS

The use of herbicides mixed with other pesticides or with fertilizers is not new but it is growing in popularity. The biggest advantage to farmers is the savings in time and labor and number of trips across fields. Yields can be as good with combination applications as with split applications. Research has confirmed that herbicides applied with some fertilizers can perform as well as with single applications. 
Most herbicides are specific and their activity is not the same toward all weeds. For example, trifluralin does not control nightshade species in beans and alachlor is weak on kochia. Because of these and other limitations of single herbicides, interest in mixing herbicides to control a broader spectrum of weeds and provide more consistent control over a wide range of climatic conditions has increased. Combinations can also lower the rates of application necessary and thus decrease crop injury and soil persistence.

There is a possibility of synergistic (additive) effects resulting in increased herbicidal activity beyond that of either single chemical. There can also be an antagonistic effect in which injury to the weeds may be less than with either chemical alone. There are limitations and concerns about mixing chemicals without research data. Herbicides should not be mixed with other herbicides or fertilizers unless the combination has been thoroughly researched and is registered for use.

The following factors should be considered before mixing herbicides with any pesticide or fertilizer.

1. Pesticides vary greatly in their physical and chemical compatibility with each other and with fertilizers. In many cases there can be a physical inactivation when two formulations precipitate out of solution. There can also be a chemical reaction and inactivation between two incompatible products. A small scale test for physical compatibility is recommended if the applicator has no previous experience with the mixture. Mix proper concentrations of the chemicals to be tested with the proper amount of carrier in a wide-mouth one quart jar. Agitate well and let stand over night. Check for precipitate in the bottom of the jar. This will only indicate physical compatibility - not possible chemical incompatibility, or synergistic or antagonistic effects.

2. Agitation (keeping an herbicide uniformly dispersed in a mixture) is also important. It is a general rule to never add a wettable powder to the surface of a full or nearly full tank of liquid. Slurry the powder before adding it to the tank.

3. Optimum placement of each product may rule out a combination application. Some fertilizers are incorporated fairly deep, while many herbicides need shallow incorporation or are left on the soil surface. Some fertilizers are broadcast while others should be soil incorporated. Each herbicide must be considered separately. Correct placement of the herbicide should have preference.

4. The applicator must determine if the timing of the application, placement, and distribution of each component of the mixture is similar enough to be applied as a mixture. 
Often the application time is different for herbicides and fertilizers. Optimum time for herbicide application is usually just before planting, during planting, or soon after planting. Fertilizers are often applied in the fall or early spring. Again, correct timing should have preference.

\section{G. HERBICIDE APPLICATION}

Ideal application techniques provide uniform distribution of the herbicide on plant foliage or in the soil. Chemical formulation will usually dictate what type of equipment should be used for application.

1. Spraying is the most common method of application. A spray may be defined as liquid discharged so that it subdivides into particles that scatter and fall as dispersed dr plets. Spraying permits reasonably uniform application ano allows accurate direction of the herbicide to a given area (such as foliage or soil). Sprays may be applied from sprinkler cans, hand pumps, and compressed air and power sprayers. Most available herbicides can be sprayed using a water carrier. Water acidity or alkalinity can chemically affect an herbicide and inactivate it. If this is a concern water pH should be tested.

2. Granules are spread by hand or with special mechanical spreaders designed specifically for such use. Applicators may broadcast the granules evenly over the entire spreader width or in bands over the crop row. These applicators are generally refined fertilizer applicators or seeders and may include equipment for soil incorporation. Granular herbicides have the advantage of being less bulky since they are premixed and eliminate the need to handle water. The equipment is also less complex. The major disadvantages include lack of uniform herbicide distribution and lack of versatility of equipment. Granulars are often more expensive than sprays.

3. Fumigants are injected into the soil by both hand and power-operated equipment. The utility of this equipment is obviously limited and cost of application is generally very high. Fumigants demand caution in handling since they are highly volatile and extremely toxic. Usually airtight covers must be laid down over treated areas to prevent escape of vapors. Fumigants will give increased control for soil insects, nematodes, and some plant diseases, as well as

For more complete information on sprayer calibration and spray equipment maintenance, please refer to the Montana Department of Agriculture Basic Pesticide Equipment Manual. 


\section{CHAPTER V}

\section{CHEMICALS USED AS CROP AIDS}

\section{A. DEFOLIANTS AND DESICCANTS}

Materials generally referred to as harvest aid chemicals fall into two classes: 1) defoliants that induce the plant to drop its leaves but do not kill the plant; and 2) desiccants that kill plant foliage. These classifications often overlap, depending upon the amount of chemical applied. Before the use of chemicals to defoliate plants, root crops, such as potatoes, were defoliated mechanically with rubber flails or chains. In many areas, contact chemical vine killers, have replaced machines, giving growers a method of artificially hastening the maturity of the crop. Desiccation of seed alfalfa plants is common in some areas and has replaced mowing and wind-rowing in harvesting alfalfa seed. When weather conditions do not favor drying, bean fields can remain green until frost. Desiccation and pre-harvest drying is beneficial in these cases. There is also considerable interest in the use of dessicants to speed up drying of crops, such as soybeans, in the field rather than depending on heat for drying after the crop is harvested.

Some of the commonly used defoliants or desiccants registered by the EPA are: paraquat and diquat, DNEP, endothall, pentachlorophenol, sodium borate, and sodium chlorate.

1. Timing of the desiccant is the most important factor affecting efficient use of the chemical. The crop must be sufficiently mature before growth is stopped. Often varying degrees of maturity are found throughout a field and the applicator must judge the correct time to defoliate. It is also important to know when harvesting can begin after treatment, as the crop will usually not stand up to much wet weather after a desiccant is applied. This is especially important when using a desiccant on an alfalfa seed crop or beans.

2. Additives can improve defoliation and desiccation, especially when there are corditions of moisture stress or cool weather. Some harvest aid chemicals are formulated with additives.

B. PLANT GROWTH REGULATORS

Plant growth regulators (PGRs) are used to regulate or modify the growth of plants. A plant is made up of many cells with specialized functions. Plant growth regulators can change or regulate the development of these cells. PGRs are used to thin apples, control the height of turf grass, control the height of some floral potted plants, promote dense growth of ornamentals, and stimulate rooting. They are used in minute amounts to 
change, speed up, stop, retard, or in some way influence vegetative or reproductive growth of a plant.

Maleic hydrazide is a plant growth regulator that restricts development of new growth by preventing further cell division. The older cells, although affected by the chemical, may continue to grow. In other words, cell division, but not cell maturity, is prevented. Maleic hydrazide is also sometimes used to control suckers.

Potted plants, such as chrysanthemums, Easter lilies, and poinsettias, may grow too tall. Plant height can be regulated with growth regulators that are applied at the proper stage of growth. Plant growth regulators are used to control vegetative growth and promote earlier flowering and development in some species. Some are used to kill shoot tips, resulting in additic nal branching.

Plant growth regulators are used on apples and peaches to increase fruit color and may result in earlier and more more uniform ripening of fruit. They can also be used to thin the fruit, widen branch angles, produce more flower buds, prevent fruit drop, increase fruit firmness, reduce fruit cracking, reduce storage problems, and encourage more uniform fruit bearing.

Rooting hormones are used to increase the development of roots and speed up rooting of certain plants.

Gibberellic acid stimulates plant growth. This is sometimes used to initiate uniform sprouting of seed potatoes and increase the size of sweet cherries. 
ENVIRONMENTAL FACTORS INFLUENCING HERBICIDE EFFICACY

Rainfall, soil type and conditions, temperature, light and crop type all have a direct effect on herbicide efficacy. Understanding these effects aids in proper herbicide use, improves weed control, and reduces crop injury.

\section{A. RAINFALL}

Time of germination of crop and weed seeds, their growth rate, and stage of growth at spraying time are partially determined by the incidence and amount of rain. Rain a few days before spraying can improve penetration of an herbicide into a plant by increasing the wettability of the leaf. Rain may mechanically damage the wax structure of the leaf surface, making the plant more susceptible to chemical absorption. The wax, cuticle and hair on the leaf surface, the angle of the leaf, and the humidity of the air help to determine how much chemical is retained and absorbed.

Rain, during or closely following application of an herbicide, may wash the spray from the leaves and reduce its effectiveness. The degree of leaf washing depends, not only on the quantity of rain and its intensity, but also on the structure of the crop-weed stand. The leaf penetration of herbicides ceases, or is reduced, a few hours after application when droplets have dried. Traces of rain, dew, or fog after spraying increase penetration.

The relative humidity at the time of chemical application and for many days after application, will effect the degree of weed kill. Moist air increases herbicide penetration, absorption, and translocation within the weed. Crop density and stand height also effects the relative humidity in the area.

B. SOIL

Soil composition and moisture influences herbicide persistence. The length of time that an herbicide remains active or persists in the soil influences to the length of time weed control can be expected. It also determines the length of time until a sensitive crop can be grown in a treated area. Persistence is a desirable or undesirable characteristic depending on the crops to be grown or the weeds to be controlled.

1. Soil moisture, rainfall or irrigation is essential in a successful weed control program. Sufficient moisture stimulates uniform germination of weed seeds and vigorous growth of the plant. Chemical application under these 
conditions is more likely to succeed than when the soil is dry prior to treatment.

Dry conditions cause uneven germination of the weeds and delay crop development. As a result, proper timing of post-emergence herbicides is difficult. Weeds will be uneven in size and difficult to kill and the crop may be at a stage where injury could occur.

Water stress can affect herbicide retention, penetration, and absorption. Leaves grown under water stress have more cuticle per unit area and a lower wettability than leaves from plants not under stress.

2. Factors having the greatest effect on herbicide soil residues are leaching, fixation on soil particles, chemical anu microbial decomposition, and volatilization.

a. Leaching is the movement of an herbicide through the soil. The extent to which a chemical is leached depends upon its solubility in water, the amount of water passed through the soil, and the adsorptive relationship between the herbicide and the soil. In general, water soluble herbicides and those not readily attached to soil particles are most readily leached.

b. Fixation, or adsorption, of herbicides on soil particles reduces the concentration that is available in soil water. Soils heavy in organic matter or clay type soils tend to hold the herbicide for a longer period of time, thus slowing the rate of chemical release and either prolonging or lessening its effectiveness, depending on the rate of application.

c. Chemical decomposition, involving reactions such as oxidation, reduction, and hydrolysis, destroys most herbicides and activates others. Very little is known about the effects of soil chemistry on herbicides.

d. Microorganisms in the soil are responsible for much herbicide decomposition. Algae, fungi, and bacteria need food for energy and growth. Organic compounds in the soil, including herbicides, provide most of this food. Warm, moist, well-aerated, fertile soils are most favorable to soil microbes and, under ideal conditions, will quickly decompose most organic herbicides. The effect of herbicides on the microbe population is minor when used at normal field rates.

e. Volatilization causes herbicide loss to the atmosphere as a gas. All chemicals have a vapor pressure and this usually increases as the temperature rises. The gases formed may be toxic to plants and may 
drift to susceptible plants. Water will leach the herbicide into the soil and aid soil adsorption. Once adsorbed, loss by volatilization is greatly reduced.

\section{TEMPERATURE}

Temperature conditions influence germination and growth rates of weeds and crops. Temperatures at the time of spraying are important in determining the plant response to the herbicide. High temperature generally increases the activity of herbicides. There is also an increase in translocation at higher temperatures. In general, high temperatures before and after spraying appear to increase weed susceptibility and mortality, but extremely high temperatures may reduce penetration by causing wilting, closing of leaf openings, and evaporation of the spray drops. High tempratures also increase the incidence of herbicide drift or volatilization.

Temperature changes produce metabolic differences in some plants which effect their susceptibility to herbicides. A plant at a low temperature may not produce a particular metabolic substance which is necessary to obtain a response to an herbicide. Tests indicate this occurs in plants such as big sagebrush or rabbitbrush, which do not respond to 2,4-D at low temperatures and low moisture. Temperature also has an effect on direction of movement in a plant. Work on mesquite shows 2,4,5-T movement toward the base of the plant at 70 degrees and toward the top at 86 degrees.

Temperatures have important effects on the dissipation of herbicides from plant foliage or from soil. Some esters of 2,4-D evaporate readily. When such herbicides are applied at high temperatures their loss as vapors is quite rapid. These losses reduce herbicide effectiveness.

D. LIGHT

Light is essential for optimum plant growth. Weed growth in a crop situation can be affected by shading. Growth response to shading will vary among species.

The leaf surface may be affected by light intensity. Leaves have less cuticle, cutin, and wax when grown in the shade. This might lead to differences in susceptibility of the leaf wax structure to weathering and abrasion. The leaf wettability increases when plants are grown in the shade.

Light (sunlight and ultraviolet light) can cause decomposition of some herbicides also. It is difficult to determine the relative importance of this phenomenon in the field where the herbicide may be lost through other factors, but it can be demonstrated under laboratory conditions. Loss from photodecomposition of such herbicides as the dinitroalinines when not soil incorporated can be important in a field situation. 


\section{WEEDS AND HERBICIDES IN THE ENVIRONMENT}

The main reason for controlling weeds is to change the environment to permit efficient production of food and fiber. All weed control practices alter the environment whether it is hand pulling, hoeing, cultivating, burning, chemical application, or use of biological control agents. Our concern is that the change in the environment does not produce harmful side effects to non-target plants, soil, water, animals, or man.

A. DRIFT AND VOLATILITY OF HERBICIDES

Herbicides, if used correctly, can be useful tools in land management programs, but if used incorrectly, they can create serious problems. With greater emphasis on a healthy environment, it is important that herbicides be applied in a proper manner. People involved in application must understand such things as spray drift and spray volatility and take precautions to prevent damage to non-target organisms.

1. Spray drift is the movement of spray particles out of an intended area. Drift is dependent mainly on a) droplet size; b) wind velocity; and c) height above the ground. A water droplet 5 microns in diameter can drift over three miles, falling 10 feet, when the wind velocity is $3 \mathrm{mph}$. Certain atmospheric conditions associated with high temperatures can cause thermal updrafts-lifting spray droplets in the air and depositing them a considerable distance away.

In the last few years, several methods of reducing drift have been attempted. The most advertised method has been invert emulsions. Esters of 2,4-D make a milk-like "oil-in-water" emulsion that sprays like water. If the emulsion is reversed (inverted) to a "water-in-oil" liquid, and with proper spray equipment, the mixture can be sprayed in large droplets. Other methods for reducing drift include using shields, placing more nozzles on the boom, reducing pressures, and use of drift control additives.

2. A considerable body of literature exists on the volatility of esters of $2,4-D$ and related compounds. Volatilization is the tendency of a sprayed material to vaporize after it has hit the soil or plant surface. Because of the small amount of material involved, volatility is usually a hazard only when extremely sensitive crops are nearby. For example, cotton is sensitive to as little as $1 / 1000$ pound per acre of $2,4-D$. Tomatoes and some ornamentals are also sensitive to 2,4-D damage.

Volatility can be controlled only by reducing the tendency of the chemical to vaporize. The major herbicide which 
causes economic crop damage due to volatility is $2,4-D$. The crystals of 2,4-D acid and amines of 2,4-D are not volatile, while ester formulations have varying degrees of volatility depending on the type of alcohol used to make the ester. Butyl, ethyl, and propyl esters of 2,4-D are very volatile and should not be used if sensitive crops are growing in the area. Iso-octyl and propylene-glycol are examples of ester formulations which are classified as low volatile and do not vaporize easily. These esters are about 10 to 20 times less volatile. However, all forms of amines are less volatile than any of the ester forms. In the last few years, attempts to reduce volatility have resulted in the formulation of $2,4-D$ acid in oil mixtures and more recently, in oil soluble amine formulations. To spray an amine with oil will usually increase its effectiveness to equal that of an ester formulation.

\section{B. PRLIECTION OF NON-TARGET PLANTS}

By far the greatest hazard associated with herbicides is the phytotoxic effect on non-target plants caused by incorrect or inaccurate application.

Spray drift, in either particle or vapor form, deposited on plant foliage; soil contamination resulting in root uptake by non-target plants; excessive soil persistence causing injury to subseguent crops; or sprayer contamination are examples of hazards that should be avoided. Due to the effects that herbicides produce on plants, their presence can be readily detected in terms of characteristic symptoms or death.

Spray drift of certain soil applied or persistant non-crop herbicides can injure susceptible non-target plants (beans, sugar beets), even when the drift occurs before seeding the crop.

Plant growth regulating (hormone-like) herbicides present the greatest visible hazard to non-target broadleaf plants. Conversion to a vapor associated with temperatures of about 90 degrees and higher can be a hazard with low volatile ester forms of $2,4-D$ and related herbicides. High volatile $2,4-D$ esters present an extreme vapor hazard and their use should be confined to areas where sensitive crops are not in close proximity.

All of the herbicides listed below are plant growth regulators and can promote abnormal plant growth when found in trace amounts. Once these herbicides are used, adequate decontamination of sprayers poses a problem, especially if the sprayer is multipurpose and must be used for application of other pesticides. Emulsifiable (oil-soluble) forms such as esters and oil soluble amines are more difficult to clean from spray equipment than the water soluble metallic and amine salts. 
Herbicides that May Present a Drift or Equipment Contamination Problem

$\begin{array}{ll}2,4-D & 2,4,5-T \\ \text { MCPA } & \text { picloram } \\ \text { MCPB } & \text { dicamba } \\ \text { silvex } & \text { fenac }\end{array}$

There are several suggested decontamination procedures (see MDA, Basic Pesticide Equipment Manual). Using the right procedure and with enough effort, decontamination can be accomplished. When using sprayers for multiple use applications, extreme care should be exercised.

It should be remembered that all herbicides are subject to drift under certain conditions. Good judgment should be used when applying any herbicide. 
Any herbicide, in large enough doses, can pose a serious health hazard. However, at recommended rates, most herbicides are relatively non-toxic to man and the environment. Herbicides, as with all pesticides, should be used only according to label directions. The information provided on the label is for the safety of the applicator as well as for anyone in the area and label directions, including use of safety equipment, should be carefully followed.

\section{A. TOXICITY CLASSIFICATION}

All pesticides are classified according to their toxicity to man. The following table indicates the relative toxicity of most herbicides to man. To find the common names of herbicides associated with the list, refer to the family classification in Appendix A.

\section{Toxicity Classes}

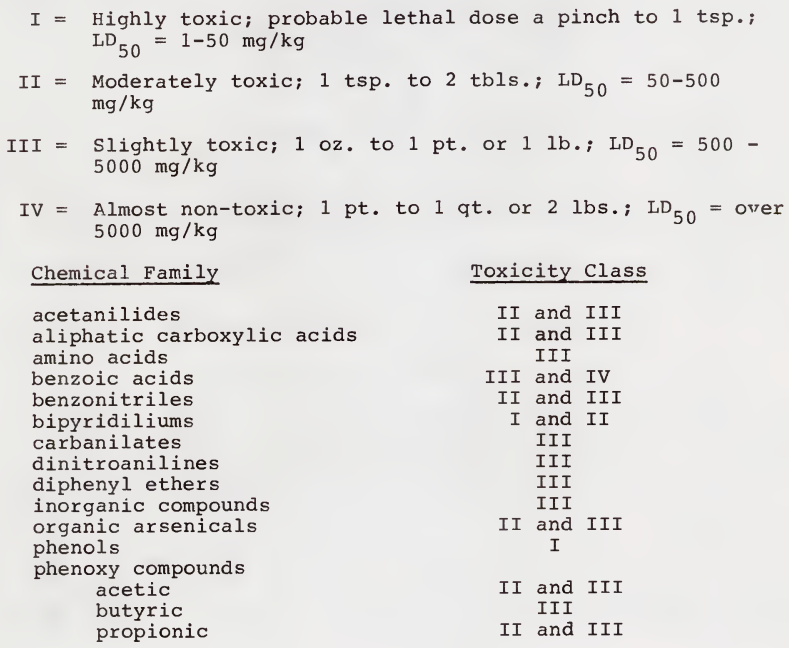


Chemical Family

phthalic acids

pyridines

pyridazinones

thiocarbamates

s-triazines

as-triazines

triazoles

uracils

ureas
Toxicity Class

II and III

III

III

III

II and III

III

II and III

II and IV

III

\section{B. $\underline{L D}_{50}$ VALUES}

Toxicity is the capacity of a substance to produce injury. The toxic action of greatest concern is the lethal dosage (LD) or the amount hat will kill. Toxicity of a given substance varies with species, age, sex, and nutritional status of the test animal as well as with the route of administration (internal or dermal).

The basis used to express acute toxicity of a pesticide is LD which is the average lethal dosage (LD) per unit of body weight required to kill one-half $(50 \%)$ of a population of test animals. The usual test animals are white rats, but may be mice, rabbits, and sometimes dogs. The most common $L^{2}$ is the acute oral toxicity, that is, the single internal absage necessary to kill half of the test animals.

The acute oral toxicity has limitations because it represents only the immediate toxicity of an internal dosage and not the chronic and cumulative effects or any skin absorption or irritation. Few herbicides are absorbed rapidly through the skin and most herbicides do not accumulate in the body to a toxic level. However, some do cause skin irritation. LD values are expressed in terms of milligrams of chemical per kilogram of body weight $(\mathrm{mg} / \mathrm{kg})$. Some conversion factors to convert to common terms are:

1 ounce $=28.38$ grams $=28,380$ milligrams

1 kilogram $=1,000$ grams $=2.2$ pounds

Therefore, an $\mathrm{LD}_{50}$ of $1,000 \mathrm{mg} / \mathrm{kg}$ would be 3 ounces of material per 180 pounds of body weight, while $L_{5}$ values of 100 would be 0.30 ounces per 180 pounds. Since toxicities depend on body weight, it would take only one-third of this amount to kill a 60-pound child and five times as much to kill a 900-pound animal.

$L D_{50}$ values are expressed on active ingredient. If a material is on Iy 50 percent active ingredient, it would take two parts of the material to make one part of the active ingredient. In some cases, adjuvants mixed with the active ingredient for formulating a pesticide may cause toxicity to differ from that of the active 
ingredient alone. For example, the $L_{50}$ of $2,4-D$ acid is 320 $\mathrm{mg} / \mathrm{kg}$, while that of the ester formulation is 500 to $600 \mathrm{mg} / \mathrm{kg}$.

The acute oral $L_{50}$ values for the active ingredient of some common herbicides are given in the table below. Remember, the lower the $L D_{50}$ value, the greater the toxicity. A common standard for comparison might be aspirin, which has an $L_{50}$ value
of $1,200 \mathrm{mg} / \mathrm{kg}$.

\section{$\mathrm{LD}_{50}$ VALUES OF SOME COMMON HERBICIDES}

\begin{tabular}{|c|c|c|}
\hline Common Name & $\begin{array}{c}\text { Acute Oral } \\
\mathrm{LD} / 50 \\
\mathrm{mg} / \mathrm{kg} \\
\end{array}$ & $\begin{array}{c}\text { Test } \\
\text { Animal }\end{array}$ \\
\hline Acrolein & 46 & rat \\
\hline Endothall, (acid) & 51 & rat \\
\hline (sodium salt) & 190 & rat \\
\hline (amine salt) & 206 & rat \\
\hline Dicamba (acid & 2900 & rat \\
\hline Dinoseb (DNBP) & 58 & rat \\
\hline Paraquat & 120 & rat \\
\hline Picloram & 8200 & rat \\
\hline 2,4-D (various formulations) & $300-1000$ & rats, guinea \\
\hline $\begin{array}{l}2,4,5-\mathrm{TP} \\
\mathrm{MCPA}\end{array}$ & $\begin{array}{l}850 \\
800\end{array}$ & $\begin{array}{l}\text { pigs, rabbits } \\
\text { rabbit }\end{array}$ \\
\hline
\end{tabular}


0

0 


\section{CHAPTER IX}

PERENNIAL WEEDS IN MONTANA

Control of perennial noxious weeds should be of concern to every landowrer in Montana. A combination of good farming and ranching management practices, cultivation, mechanical and cultural methods, biological control when available and chemicals will continue to aid the control of noxious weeds. Below is a brief description of the most serious noxious weeds threatening Montana agriculture. Those marked with an asterisk (*) are not currently found in Montana or are not widespread in the state. Management of these potential threats should include survey detection and eradication when found. For specific control information on all weeds refer to current Cooperative Extension publications. For color plates and a more complete description of these weeds refer to publications found in Appendix B. 


\section{A. BORAGE FAMILY (BORAGINACEAE)}

\section{Houndstongue (Cynoglossum officinale)}

Houndstongue is a biennial forb reproducing by seed. The plant spends the first year as a rosette but produces a 8-30 inch stem the second growing season. The stem is erect, simple, and branching near the top. Basal leaves are broad, lanceshaped, and have prominent veins. They are covered with fine, soft, white hairs. The roots are thick and black. The small purple or pinkish flowers produce seed clusters that contain 3 to 4 seeds. Each seed has a teardrop shape, is about $1 / 4 \mathrm{inch}$ long, and has a hard husk covered with barbs. These barbs easily attach to clothing, hair, and wool.

Houndstongue plants are usually found on disturbed sites along roads anc trails. They also establish in thick litter accumulations. The largest infestations of houndstongue occur in western and central Montana.

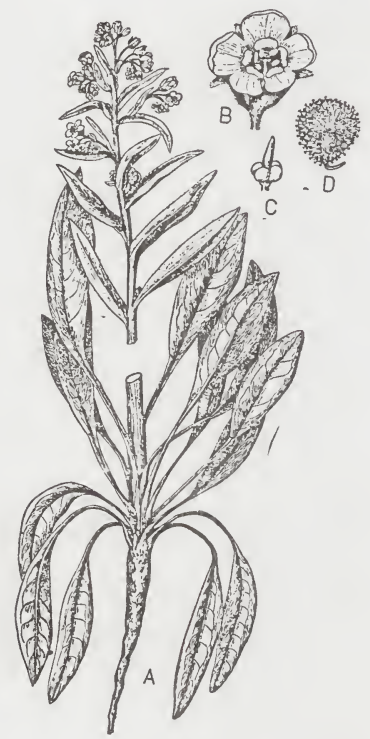

Houndstongue

A. Plant Habit

B. Flower

C. Pistil with nutlets

D. Mature nutlet 


\section{B. SUNFLOWER FAMILY (COMPOSITAE)}

\section{Common Burdock (Arctium minus)}

Common burdock is a biennial forb reproducing by seed only. First year rosette plants are fairly easy to distinquish by their large heart-shaped leaves. The leaf surface is dull green on top with a grayish wool on the lower surface. The second year seed stalk is about 4 feet tall, branched heavily near the top, and often grooved and angular. The small, purple flowers are grouped in heads surrounded by a series of bracts (involucre). The outer bracts have a hooked spine that causes the burr-like seed head to be easily transported on hair or clothing.

Burdock is commonly found in waste places with fertile soils. It may be found in neglected farmlands but rarely in cultivated areas. It can be found throughout Montana, especially in lower mountain valleys along streams.

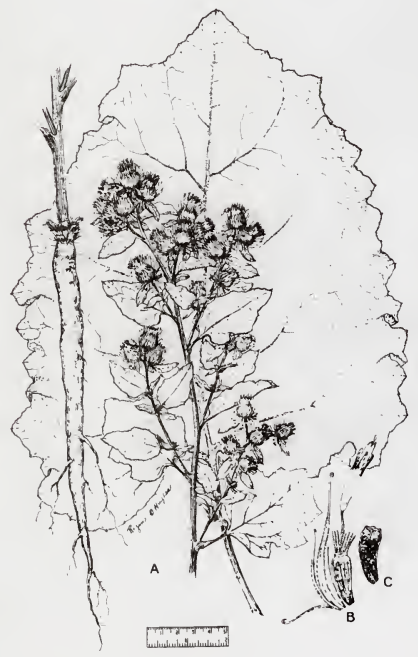

Common Burdock

A. Plant Habit

B. Flower

C. Achene 


\section{Diffuse Knapweed (Centaruea diffusa)}

Diffuse knapweed is a biennial or short-lived perennial forb that grows to a height of 1 to 3 feet. It has a taproot and only one or very few stalks. The tip of each branch has a single flower head. The flowers are most commonly white with the upper portion of the bract narrowing to a distinct spine. Often the outer most flowers are sterile. The bracts are yellowish green with a light brown margin. Seeds are achenes, dark brown, 1 inch long, with
faint pale brown or ivory lines.

Diffuse knapweed grows well in dry sites and is found on waste grounds, fields, and along roadways in many areas of western Montana. The most serious infestation is located near East

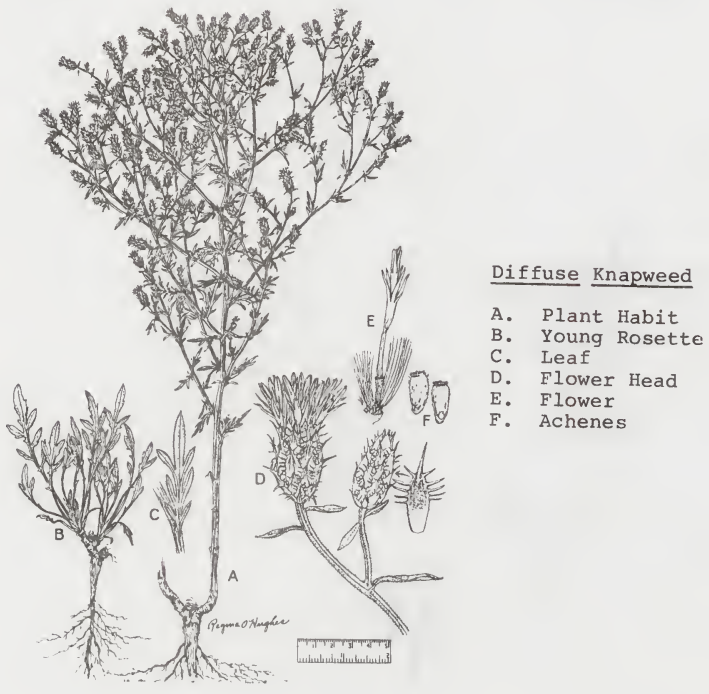




\section{Spotted knapweed (Centaurea maculosa)}

Spotted knapweed is a biennial or short-lived perennial reproducing primarily by seed. The stems are erect with slender, wiry branches, rough and hairy, and approximately 1 to 3 feet tall. Leaves are alternate with deep, narrow divisions and a rough, hairy surface. Flower heads are clustered and numerous at the top of the stems. Flowers range from pink to purple and the outer bracts are tipped with black, comb-like margins. Heads are $1 / 2$ to 1 inch in diameter. The seed is an achene, brownish with one side notched near the base. There is a short tuft of bristles at the tip end and the seeds are approximately $2 \mathrm{~mm}$ long.

Spotted knapweed is introduced and naturalized from Europe. It is often found in dry gravelly or sandy pastures, old fields, and along roadsides. It readily invades pastures and can take over nearby range and pasture. Spotted knapweed is found in every county in Montana but the heaviest infestaions are in the western part of the state.

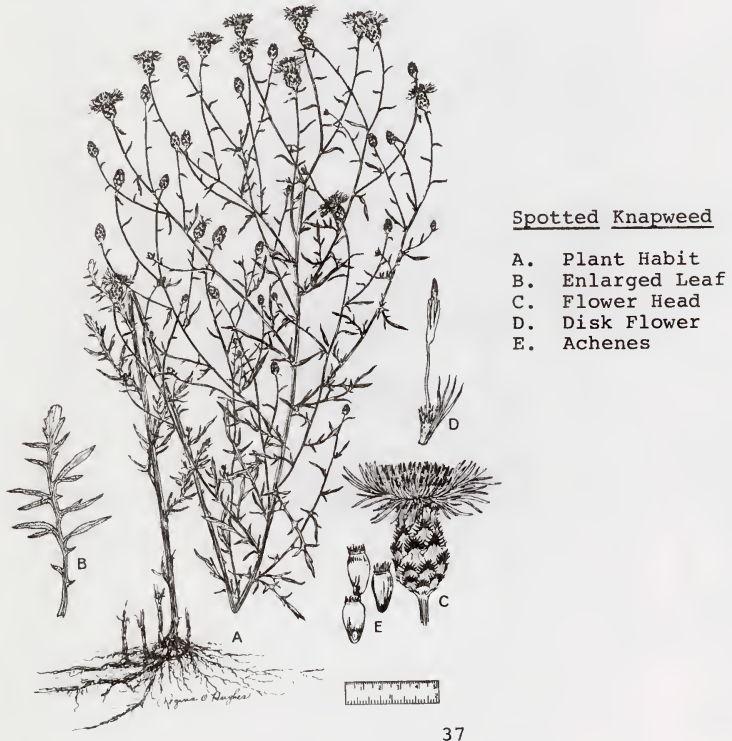




\section{Russian Knapweed (Centaurea repens)}

Russian knapweed is a bushy, branched perennial plant reproducing by seed and underground rhizomes. The roots are

characteristically black in color and have a scaly appearance. The stems are erect, 2 to 3 feet tall, branched at the base, ridged and have a dense gray hair-like covering. The basal leaves are hairy and the upper leaves are small and linear with smooth edges. The intermediate leaves have slightly toothed margins. The flowers are $1 / 2$ inch wide, rose to purple composite heads and solitary on the ends of leafy branches. The seeds are grayish to yellow, smooth, flattened, oval, and about $1 / 8$ of an inch long. The flowers generally bloom from June to August.

Russian knapweed wis introduced from southern Russia and Asia. It grows in pastures, grain fields, cultivated fields, meadows, waste plisses, roadsides, and irrigation ditches. It is found throughout Montana. Once established it will completely crowd out other vegetation.

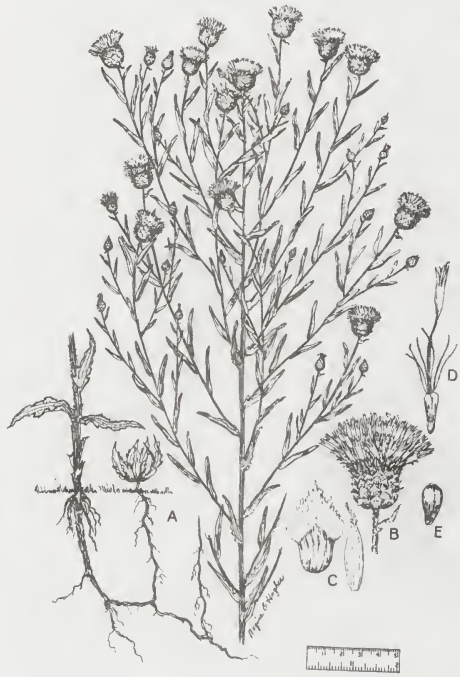

Russian Knapweed

A. Plant Habit

B. Head

C. Bracts

D. Flower

E. Achene 


\section{Yellow Starthistle (Centaurea solstitialis) *}

Yellow starthistle is commonly a winter annual but it can germinate and grow to maturity in one season. The plant is gray green in color with cottony hair on the leaves and stems. It reaches a height of 1 to 3 feet, is branched, and has a yellow flower on the end of each branch. The leaves are narrow with the base of the leaf extending along the stem, giving them a winged or ridged appearance. The flower is bright yellow and has long sharp rigid spines as bracts below each flower. Two types of seeds are produced; light colored with bristly awns and dark with no bristles.

Yellow starthistle is found in cultivated and fallow fields, pastures, rangelands and waste places. It can invade range and pasture and competes well with existing vegetaton. It crowds out existing grasses where moisture is limited and grasses are weakened from overgrazing. It produces a toxic chemical that can cause death in horses and the spines can cause serious injury to grazing animals. It is not currently found in Montana but is found in several areas of Idaho and Washington. It should be eradicated if found in Montana.

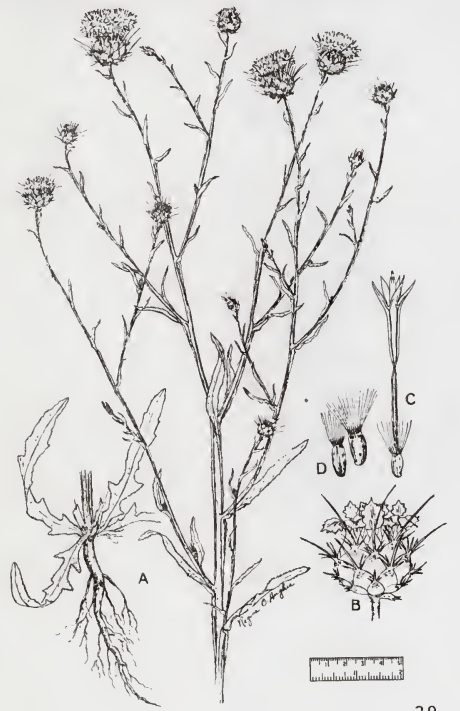

Yellow Starthistle

A. Plant Habit

B. Involucre

C. Flower

D. Achenes 


\section{Rush Skeletonweed (Chondrilla juncea) *}

Rush skeletonweed is a taprooted herbaceous perennial plant that overwinters as a compact rosette resembling an immature dandelion. The plant bolts in early spring and the flower stalk is 1 to 4 feet, nearly leafless with spreading side branches. Stem leaves are narrow and linear. The flowers are yellow, $3 / 4$ of an inch in diameter, and composed of 7 to 15 individual florets. An individual plant may produce up to 20,000 seeds. Each seed is attached to a light pappus, similar to the dandelion. Seeds have no dormancy and remain viable for only 18 months under normal environmental conditions. Taproots may extend to soil depths of 7 feet and produce lateral roots which give rise to satellite plants. Cut plant surfaces exude a milky
white latex sap.

Rush ske. stonweed generally inhabits well-drained, light soils alongs roadsides, in rangelands, grain fields and pastures. Soil disturbance aids establishment. It presently infests several million acres of rangeland in Idaho, Oregon, Washington, and California. It can potentially become a problem in cropland areas with light textured soils. It has caused an estimated $\$ 30$ million loss in Australian wheat producing areas. It is not currently found in Montana and detection and eradication programs should be initiated for the state. Cooperative detection programs have been developed for the Pacific Northwest. 


\section{Canada Thistle (Cirsium arvense)}

Canada thistle is a perennial plant reproducing by creeping horizontal roots and by seed. The extensive roots are fleshy and send up frequent new shoots. The stems are erect, hollow, smooth or slightly hairy, up to 4 feet high and branched at the top. The plants are leafy but no wings or spines occur on the stem. The wavy leaves are oblong to lance shaped and vary from irregular and deeply cut, to spiny toothed on the margins, to almost smooth with few or no spines. The color is usually bright green but the upper surface varies from dark to light and the leaves are sometimes very light green and slightly hairy on the underside. The flowers are numerous, small, compact, and vary from light lavendar or white to rose-purple. There are many flower heads clustered together on the ends of branches. Canada thistle flower heads often appear much smaller than most other thistles. The bract on the heads are not spiny. The plant is dioecious, with male and female flowers produced on separate plants. Seeds are oblong, flattened, curved, smooth, dark brown, and approximately $1 / 8$ inch long.

Canada thistle is an introduced species from Eurasia and grows throughout the northern half of the United States and north into Canada from British Columbia to Quebec. It grows in all crops, pastures, meadows, and waste places in rich, heavy soils. Canada thistle is a serious threat to grain crops in Montana. Wheat yields have been reduced from 15 to 608 in infested areas.

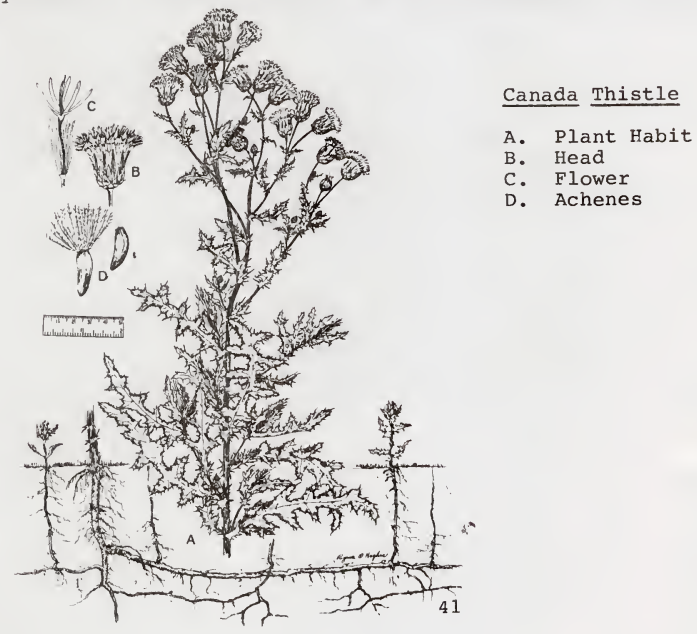




\section{Common Crupina (Crupina vulgaris) *}

Common crupina is a winter annual that reproduces by seed. It is closely related to the knapweed species. The cotyledon leaves are large, thick and dark green. They generally germinate in the fall when moisture is adequate and form a basal rosette. The true leaves are finely divided. A dense, fibrous root system develops quickly once the seedling is established. The plants overwinter as compact rosettes. In the spring the plant bolts and has a main flower stem from 1 to 4 feet tall. Leaves are alternate the length of the stem and are finely divided, lacelike leaflets. Stiff hairs on the leaf surface give them a sticky feel. Flowers are lavender to purple and are $1 / 2$ inch long. Plants produce from 5 to more than 100 flower heads. Each head produces 1 to 5 seeds. Seeds (achenes) are large, cylindrical, tapering slightly to a blunt end. They have a dark, stiff pai Jus at the basal end. Dense, fine hairs cover the seed, giving it a black to silver color.

Common crupina is generally found on well-drained, rocky to silt loam soil in pasture or rangeland. Infestations start in disturbed areas or sites with sparse vegetation. It is a recent introduction and is currently found on the federal noxious weed list. Detection and eradication programs are underway in the western United States in cooperation with the Animal and Plant Health Inspection Service (APHIS). Current infestations are found only in three counties in Idaho. An effort must be made to keep this weed out of Montana. 


\section{Tansy Ragwort (Senecio jacobaea) *}

Tansy ragwort is a biennial or short-lived perennial plant. Most seeds germinate in the fall, form a rosette the following year and flower and set seed the next year. If the plant is cut, pullod or broken the second year this damage results in regrowth and blossoming during the third year. Tansy ragwort has daisylike golden flowers with a long blossoming period. The rosettes have irregular, lobed leaves with a visible blade region near the tip. The stems are 1 to 6 feet high. The leaves, 5 to 9 inches long, are attached directly to the main stalk. Leaf color may vary fron light to dark green. The plant spreads principally by seeds, and individual plants may have as many as 150,000 seeds.

Tansy ragwort is a native of Europe. It grows well in pastures and disurbed areas on a wide range of soil types. It can survive under most soil moisture conditions and does well through the Northwest area. Hot dry summer and very low $(-20)$ winter temperatures do not adversely affect this plant. The plant is toxic to both cattle and horses, and to some extent sheep. Alkaloids found in all parts of the plant cause irreversible liver damage. This plant is currently one of the most serious weed problems in oregon and is also found in northern California, western Washington and British Columbia. It is found in limited areas of Montana and detection and eradication should be attempted.

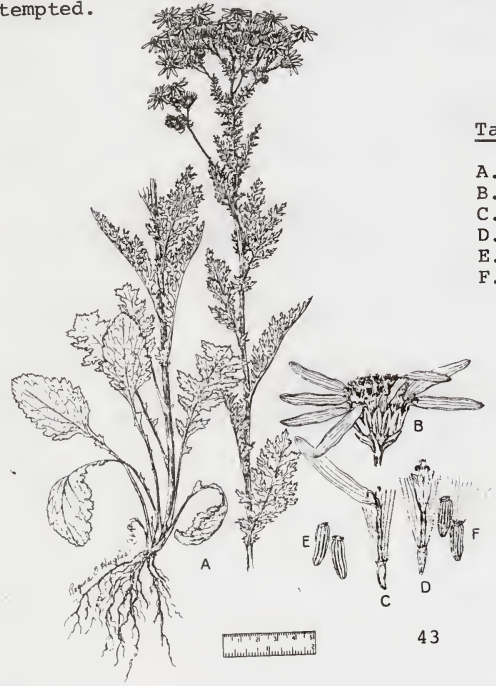

Tansy Ragwort

A. Plant Habit

B. Flower Head

C. Ray Flower

D. Disk Flower

E. Achenes (ray flower)

F. Achenes (disk flower)

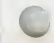




\section{MORNINGGLORY FAMILY (CONVOLVULACEAE)}

\section{Field Bindweed (Convolvulus arvensis)}

Field bindweed is a viny, weak-stemmed, persistent perennial weed. It reproduces from an extensive root stock, rhizomes, and abundantly produced seeds. The plant forms a mat on the soil surface with prostrate stems 2 to 7 feet long that can climb short distances. The roots may extend 20 to 30 feet into the soil. The leaves are dull green and vary in size and shape, depending on soil fertility and moisture. Characteristically, they are ovate oblong with acute spreading basal lobes. The leaves have short leaf stalks that alternate on the stem. The plants flower from May to August and the flowers are white to inch sta'ks in the leaf axis. A pair of narrow, pointed leaflike structure (bracts) are found on the flower stalks $1 / 2$ to 1 inch below the flower. The seed pod is round, pointed, light brown, and contains four seeds. The seeds are dark-brown with a roughened surface, three-angled, and $1 / 8$ to $1 / 5$ inch long.

This plant was introduced from Eurasia and is now found throughout the United States except in the extreme Southeast and a few areas in the Southwest. It grows well under most cultivated conditions as well as in all uncultivated and waste places. It is extremely difficult to eradicate due to it's low growth and widespread, deeply penetrating root system. It is a serious problem in cropland in Montana.

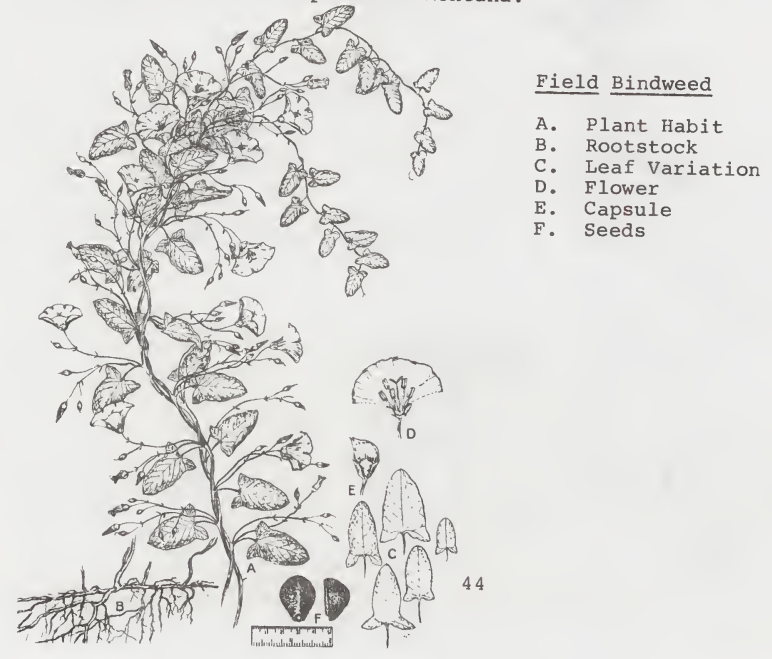




\section{MUSTARD FAMILY (CRUCIFERAE)}

\section{Whitetop (Cardaria draba)}

Whitetop (hoary cress) is a perennial reproducing by seed and rhizomes. It has numerous erect stems 1 to 2 feet high that are branched at the top. An extensive root system spreads both horizontaly and vertically with frequent shoots arising from the root stock. The plant seems to be gray green due to many fine hairs on the leaves. The leaves are simple, alternate, oblong, toothed and the upper leaves have a broad clasping base. The flowers are white, four parted, about $1 / 8$ inch wide and borne in flat-topped clusteres. Seed pods are slightly flattened, twovalved, heart-shaped with a prominent persisting style. The seeds are oval, slightly flattened, granular with reddish-brown seed coats.

Whitetop is naturalized from Europe and found throughout the United States except in the Southcentral area. It is found in pastures, cultivated fields, hay fields, meadows, waste places, and roadsides. It is most common in western and central Montana.

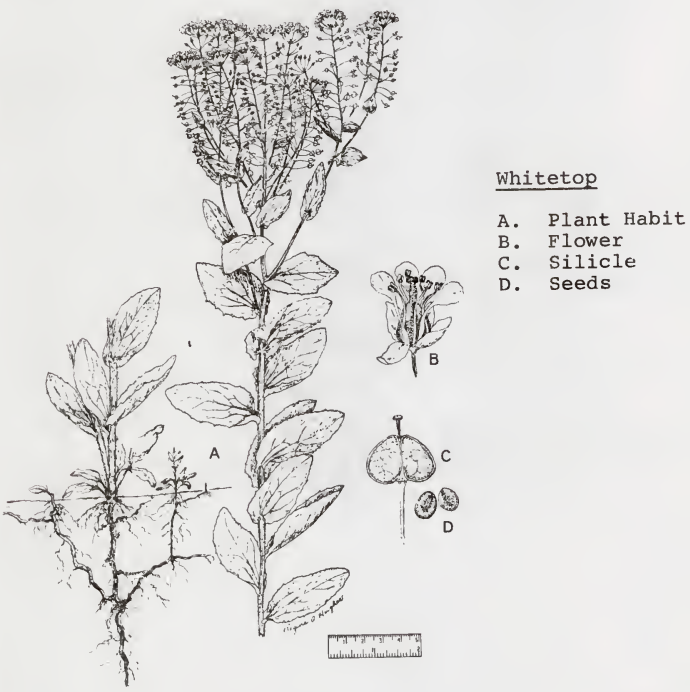




\section{Dyers Woad (Isatis tinctoria)*}

Dyers woad is a perennial, biennial or annual forb reproducing by seeds and from roots. The plants may grow from 1 to 3 feet tall and have a smooth, bluish-green color. The lower leaves are lance-shaped with short stems and the upper leaves clasp the stem with ear-like projections. The yellow flowers are very small and form a flat-topped inflorescence. The seed pods are about $1 / 2$ inch long, winged like a maple seed and turn black when mature.

Dyers woad is native to Europe. It's name comes from Germany where dye was extracted from the purplish seed pods. It is a serious weed problem in both Utah and Idaho and can be found in several locations in Montana. It spreads readily by seed from roadsides to rangel and and crops. Detection and eradication is imperati'e for Montana.

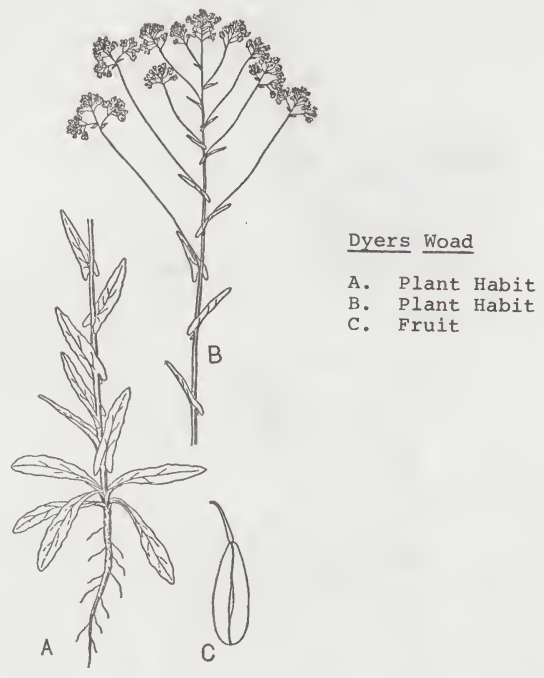




\section{E. SPURGE FAMILY (EUPHORBIACEAE)}

\section{Leafy Spurge (Euphorbia esula)}

Leafy spurge is a perennial, reproducing by seed as well as an extensive underground rhizome system. The heavy running roots are woody, persistent and widespread and give rise to dense colonies of the plant. Creeping rhizomes give rise to roots and shoots every few inches from pink buds. The stems are erect, smooth, and branched at the top. The entire plant is a dull green color with milky juice and grows about 2 feet tall. The leaves are alternate and irregularly spaced along the stem. There is a whorl of lance-shaped leaves at the base of the umbel. The flowers are inconspicuous and are formed above pairs of rounded floral bracts on repeated forking stems arranged in a flat-topped umbel. When in full bloom the entire umbel, including the bract, turns a bright greenish yellow. The seed pods are on a short stalk from the cup-like base and are three angled. There are three ovoid, smooth, light gray to brownish seeds in each pod.

Leafy spurge is an introduced plant from Europe. It is found in most of the northern United States and Canada. It grows readily in waste areas, pastures, roadsides, cultivated fields and sandy banks. It can be toxic to cattle, but sheep do well eating it. Leafy spurge is one of the most persistent noxious weeds in Montana. It is found throughout the state and has a wide habitat suitability, prolific reproduction capabilities, strong competitive ability and is difficult to control.

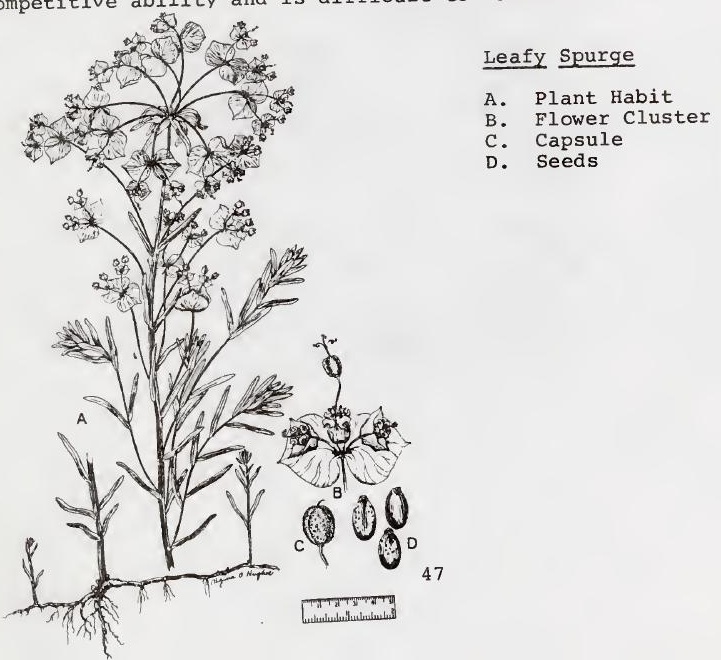


F. ST. JOHNSWORT FAMILY (HYPERICACEAE)

1. St. Johnswort (Hypericum perforatum)

St. Johnswort (goatweed, Klamath weed) is a perennial forb reproducing by seed and from rootstock. Stems are smooth, branched, about 3 feet tall and woody at the base. The opposite The orange-yellow to oblong and have small, glandular dots. five-petaled. contain many seeds.

St. Johnswort is common in dry pastures, rangelands, and neglected fields and along roadsides in western Montana. It is not readily grazed by livestock and causes photosensitization in plant. it is difficult to control be regarded as a poisonous

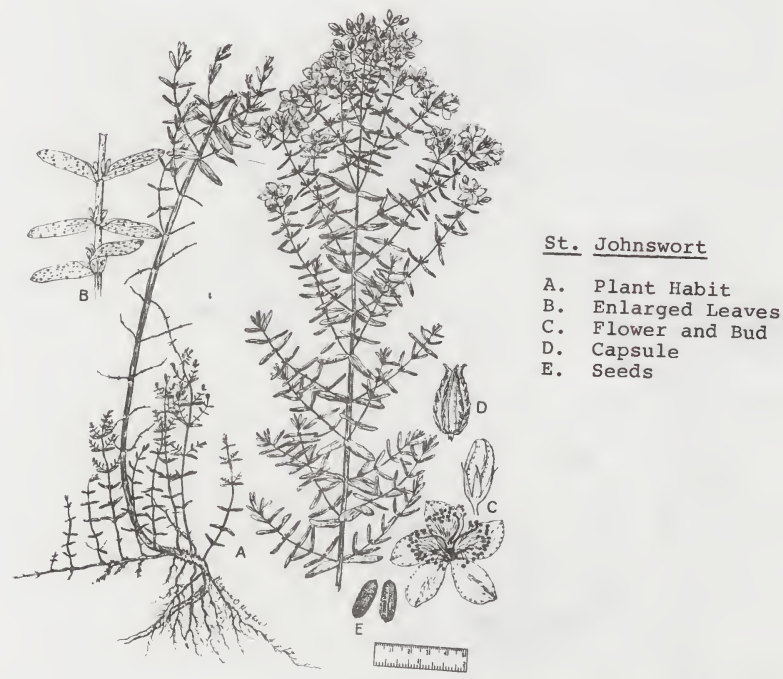




\section{G. WATERMILFOIL FAMILY (HALORAGACEAE)}

1. Eurasian Watermilfoil (Myriophyllum spicatum) *

Eurasian watermilfoil is an aquatic plant, completely submerged excent at flowering time. The leaves are whorled, 3 to 5 per node, and dissected into 13 to 23 thread-like segments. The inflorescence is emergent and unbranched. Flowers are very small, unisexual and borne in the axils of bracts. Fruits are $1 / 8$ inch long or less.

Eurasian watermilfoil is a native of Eurasia and Africa. It is found in fresh and saline waters as well as on muck to hard packed sand. Infestations occur in British Columbia, Oregon and Washington. It forms dense mats of submersed vegetation that create problems for recreation, wildlife habitiat, and may clog streams and irrigation systems. Small broken pieces will regenerate and it is spread effectively by boats moving between bodies of water. Once established it reproduces rapidiy and is difficult to control. It is not currently found in Montana and a detection and eradication program should be established for Montana.

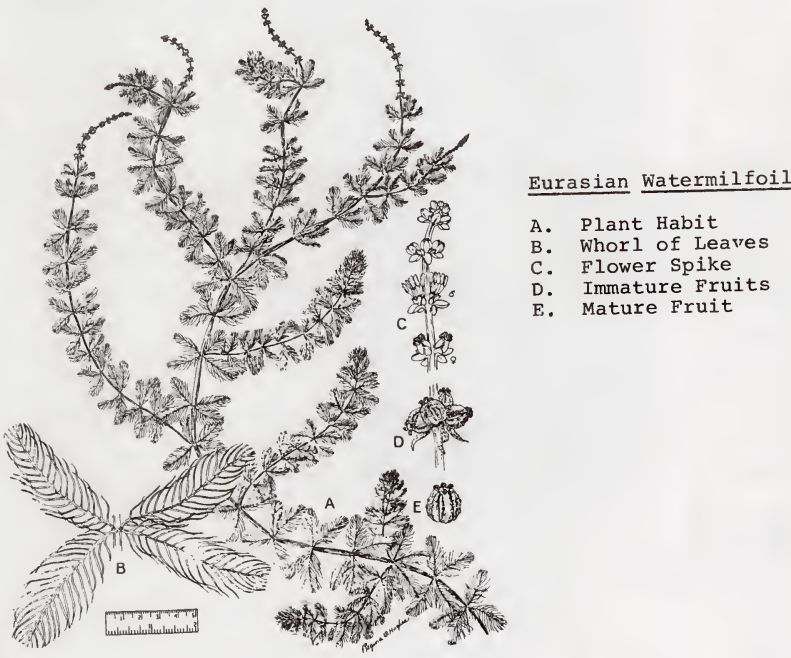




\section{H. SNAPDRAGON FAMILY (SCROPHULARIACEAE) \\ 1. Dalmation Toadflax (Linaria dalmatica)}

Dalamation toadflax is a perennial reproducing by seeds and creeping rootstocks. The plants are erect, about 2 feet tall, pale green and have showy, yellow flowers. The spurred flowers are tinged with orange and are about 1 inch long. The leave are
broad, heart-shaped, and clasp the stem.

Dalamation toadflax is a native of the Mediterranean regio found scattered throughout the northern and western United States. It is an escaped ornamental found along roadsides and near dwellings, spreading to valleys and sagebrush flats. Large infestations are found in several Montana counties.

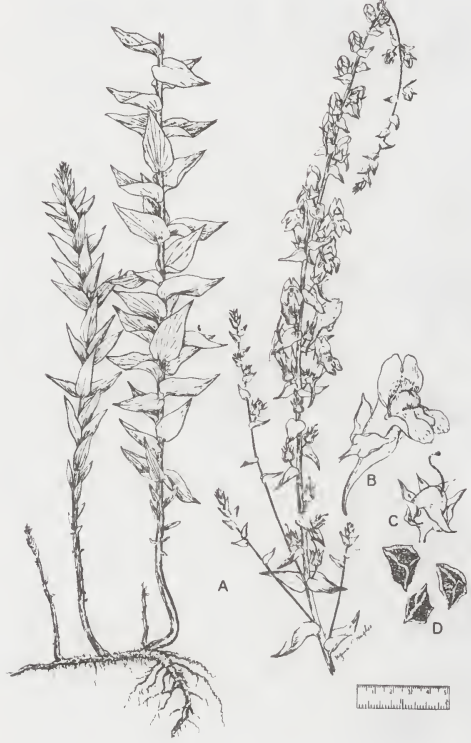

Dalmation Toadflax

A. Plant Habit

B. Flower

C. Capsule

D. Seeds 


\section{APPENDIX A}

\section{CLASSIFICATION OF HERBICIDES \\ BY CHEMICAL FAMILIES AND MODE OF ACTION}

\section{Chemical Family Common Name \\ acetanilides

$$
\begin{aligned}
& \text { alachlor } \\
& \text { bensulide } \\
& \text { diphenamid } \\
& \text { pronamide } \\
& \text { propachlor }
\end{aligned}
$$$$
\text { prynachlor }
$$$$
\begin{aligned}
& \text { alphatic carboxylic } \\
& \text { acids }
\end{aligned}
$$

benzoic acids

chloramben

dicamba

$2,3,6-\mathrm{TBA}$
benzonitriles
bipyridiliums
carbanilates

dinitroanilines

$$
\begin{aligned}
& \text { benefin } \\
& \text { dinitramine } \\
& \text { fluchloralin } \\
& \text { nitralin } \\
& \text { profluralin } \\
& \text { trifluralin }
\end{aligned}
$$

diphenyl ethers bifenox
inorganic compounds AMS
boron

$$
\text { copper sulfate }
$$$$
\text { sodium chlorate }
$$

$\begin{aligned} & \text { organic arsenicals } \text { DSMA } \\ & \text { MAA } \\ & \text { MSMA }\end{aligned}$

phenols
Trade Name

Lasso

Betasan, Prefar

Dymid, Enide

Kerb

Ramrod

Basamaize

Dowpon, Basfapon

various

Amiben

Banvel

Trysben, Benzac

\section{Casoron}

Brominil, Buctril

Ortho Diquat

Ortho Paraquat

Chloro-IPC, Furloe

GI

Carbyne

Betana 1

Balan

Cobex

Basalin

Planavin

Tolban

Treflan

Modown

C

Ammate

Borax, Borascue

Bluestone, Cutrine

Atlacide, others

$$
\begin{aligned}
& \text { various } \\
& \text { various } \\
& \text { various } \\
& \text { Premerge, Sinox }
\end{aligned}
$$

MI

GR

PI

C

MP

C

UC

C 


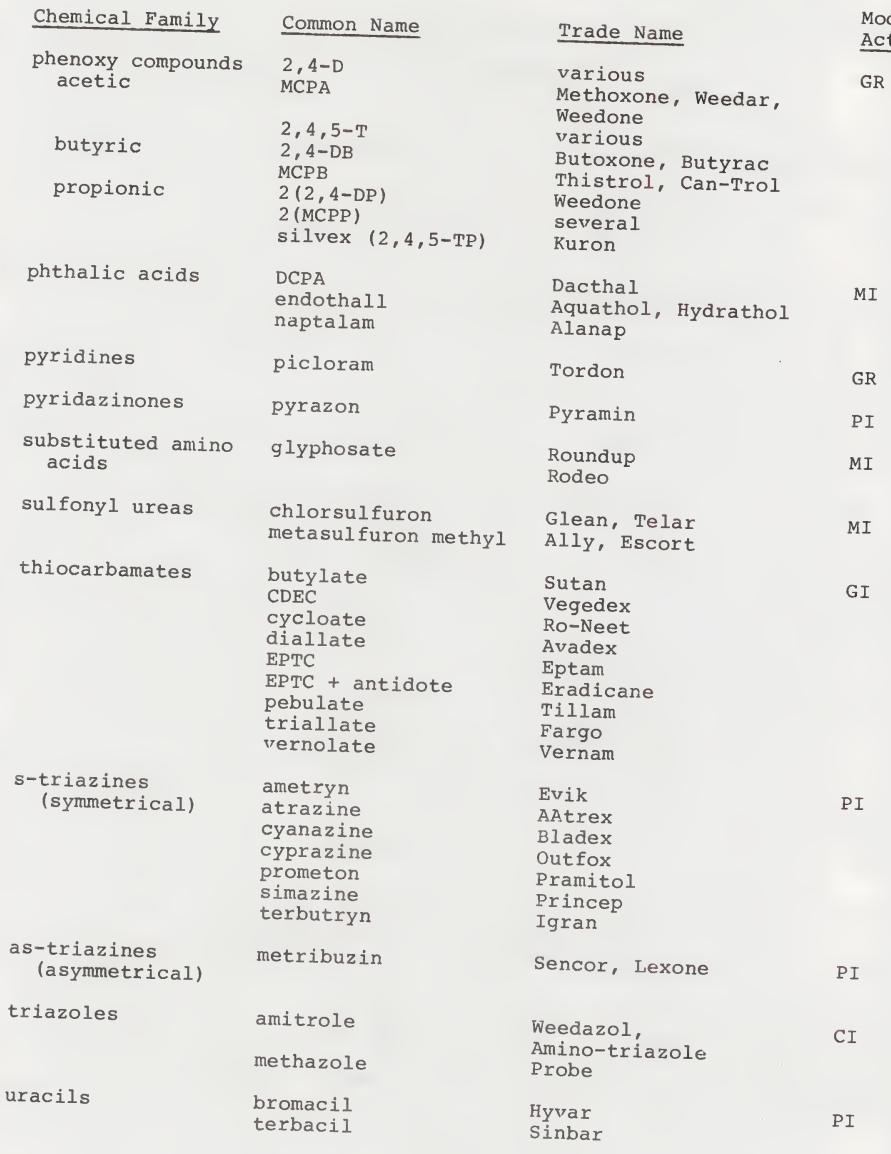


Chemical Family

ureas
Common Name

chloroxuron

diuron

fenuron

linuron

monuron

siduron
Trade Name

Tenoran, Norex

Karmex

Dybar

Lorox

Telvar

Tupersan
Mode of

Action

PI

*Mode of Action

$$
\begin{aligned}
& \text { MI = Metabolic Inhibitors } \\
& \text { GR }=\text { Growth Regulators } \\
& \text { PI }=\text { Photosynthetic Inhibitors } \\
& \text { GI }=\text { Growth Inhibitors } \\
& \text { MP }=\text { Mitotic Poisons } \\
& \text { C }=\text { Contact Herbicides } \\
& \text { UC }=\text { Unclear } \\
& \text { CI }=\text { Chlorophyll Inhibitors }
\end{aligned}
$$


$\frac{\text { Selected Weeds of the United States, USDA, ARS, Agriculture }}{\text { Handbook No. } 366, \text { March, } 1970 .}$ Weeds, Walter Conrad Muenscher.

Nebraska Weeds, Nebraska Department of Agriculture.

Weeds of Eastern Washington and Adjacent Areas, Xerpha M. Gaines Applier? Weed Science, Merrill A. Ross and Carole A. Lembi

Flora of the Pacific Northwest, C. Leo Hitchcock and Arthur Weed Biology and Control, Thomas J. Muzik. Weed Science: Principles and Practices, 2nd edition, Glenn C. Modern Weed Control, Alden S. Crafts.

Herbicide Handbook, Weed Sciene Society of America. Mode of Action of Herbicides, Floyd A. Aston and Alden S. Crafts.

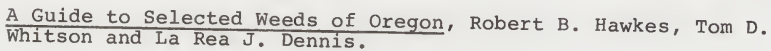
$\frac{\text { Controlling Pasture and Range Weeds in Montana, CES Bulletin 362, }}{\text { John R. Lacey and Celestine A. Lacey. }}$ 
$\theta$

c 
0

त

$+1$

0 